\title{
COLleCtive STRATEgies AND WindFALl CATCHES: fisher responses to tsunami relief efforts in South India
}

\author{
Transforming Cultures eJournal, \\ Vol. 3 No 2, November 2008 \\ http://epress.lib.uts.edu.au/journals/TfC
}

\section{Maarten Bavinck ${ }^{1}$}

University of Amsterdam, j.m.bavinck@uva.nl ${ }^{2}$

\begin{abstract}
To the surprise of both governments and NGOs, village-level caste organisations or panchayats - played a significant role in the post-tsunami relief effort to fishermen in Tamil Nadu, India. This paper discusses the pro-active role of caste panchayats in relief from the perspective of social resilience, a factor that is frequently argued to be of importance for disaster management. It presents panchayat action as an expression of collective agency that has a long tradition in the fishing villages of the region. Finally, comparing the reactions of caste panchayats in the post-tsunami situation with their performance in other instances of collective need, it considers their future role in fields such as fisheries management.
\end{abstract}

\section{Introduction}

The tsunami that hit the mainland of southeast India on 26 December 2004, devastated a thickly populated coastline many hundreds of kilometers in length. The relief effort that subsequently took place, locally known as the 'second tsunami', targeted the fishing population that was considered to have suffered most. To the surprise of the first relief workers, they were met not by victims in shock, but by the representatives of nongovernmental fisher caste councils, called uur panchayats (Tamil for village council). These councils - not to be confused with the local bodies termed Panchayats which con-

\footnotetext{
${ }^{1}$ Maarten Bavinck is Director of the Centre for Maritime Research at the University of Amsterdam and has a particular interest in legal pluralism.

${ }^{2}$ I am grateful to V.Salagrama and V.Vivekanandan for their helpful comments on an earlier draft of this paper. Preliminary versions were presented at the $13^{\text {th }}$ biennial IIFET conference entitled Rebuilding fisheries in a uncertain environment, in Portsmouth, UK, on 11-14 July 2006, and at the conference entitled Culture and commerce in the Indian Ocean, which took place in Leiden on 25-27 September, 2006.
} 
constitute the lowest tier of India's governmental structure ${ }^{3}$ - played an important role in the formulation of needs and in the distribution of relief and rehabilitation items. This continues to the present day.

The tsunami has thus contributed to a rethinking of community, or caste, organisations in India. These have been held in official disregard since the independence movement, and later the Constitution of the Republic of India, proclaimed the equality of all citzens and prohibited discrimination on grounds of caste (Art.14 and 15). The positive role of uur panchayats in regulating the fisheries of South India has, however, recently been pointed out by Bavinck (2001a,b; 2003; 2005), Salagrama (2005), Lobe and Berkes (2004) and Rajan (2004). Government agencies, such as the Fisheries Department of Tamil Nadu, have tended to overlook - if not look down upon - their contributions. Courts too have been harsh in their opinion of the judiciary action of caste councils. Six months prior to the tsunami, on 8 April 2004, the Madras High Court (Crl O.P. No. 28886 of 2003) overturned the ruling of a related institution, called katta panchayat, urging government to 'publicise the existing provisions of law...making the public know about their rights to approach the authorities against Katta Panchayat's punishment' and asking for an ordinance 'eliminating' such practices.

The surprising performance of uur panchayats in the post-tsunami relief period is relevant to the need for attention to the resilience of social and ecological systems. According to Adger et al. (2005:1038), 'social resilience, including institutions for collective action, robust governance systems, and a diversity of livelihood choices are important assets for buffering the effects of extreme natural hazards and promoting social reorganisation'. These authors thus argue that 'coastal communities harboring knowledgeable, prepared, and responsive institutions' are more likely to prevent extreme natural hazards from becoming longer-term social disasters. The Coromandel Coast situation appears to be a case in point.

\footnotetext{
${ }^{3}$ Mandelbaum (1970) provides the fullest account of the incidence, form and meaning of nongovernmental, caste councils in India. Rao and Singh (2005) describe the institutional reform, which resulted in constitutional status for local bodies termed Panchayat. In order to minimise confusion, in this paper we refer to the non-governmental councils as uur panchayats, and to the governmental bodies as Panchayats upper-cased).
} 
But the activities of uur panchayats also teach us about human agency in the context of development intervention. Long (2001:13) argues that social actors - any entity that is capable of taking decisions and acting upon them - are not 'passive recipients of intervention, but [...] active participants who process information and strategise in their dealings with various local actors as well as with outside institutions and personnel'. Always possessing a minimum of power, or room for manoeuvre, actors develop strategies 'to resolve their livelihood problems and organise their resources' (ibid.:27). Such strategies are anchored in 'actors' lived experiences, desires, understandings and selfdefined problematic situations', rather than in a universal form of rationality. The recipients of planned intervention, such as disaster relief, are, in other words, far from passive. They organise themselves with the aim of achieving the goals that they, from their 'lived experience', consider to be important.

In line with this analysis, Fernando and Hilhorst (2006) make a study of tsunami relief programmes implemented in Sri Lanka. They emphasise 'the importance of grounding the analysis of humanitarian aid in an understanding of everyday practice' (ibid:292) and highlight what they call the 'petty normality' of humanitarian aid, as well as its political dimensions (ibid:301). This paper, which highlights the condition of aid recipients, contributes to the same effort.

In this paper I review the course of affairs in the post-tsunami relief period, focusing particularly on rural areas along the Coromandel Coast of Tamil Nadu, portions of which were severely effected. This region is known for its strong fisher institutions. After discussing the role of uur panchayats in regular fishing life, I consider their performance in the period after the tsunami, focusing on the distribution of relief and rehabilitation goods as well as on the issue of habitat relocation.

The research on which this paper is based took place over a period of ten years. In the course of my studies on the social dynamics of fisheries along the northern Coromandel Coast, I have striven to obtain a general understanding, in combination with a more detailed and in-depth knowledge, of several specific fishing sites. One of these sites happened to be the fishing hamlet Kalvimanagar (a pseudonym), which will be introduced further on in this paper. I spent a great deal of time in Kalvimanagar in the period 199596 , returning every year for a short visit in order to keep track of people and events. I 
happened to be in the area again a week after the tsunami took place, staying around on some other business for another month. All in all this provided me with the chance to see how the inhabitants of the hamlet coped with the new situation. Information from other sources completed the picture, which I have tried to sketch in this paper.

One point remains to be noted. Kalvimanagar is located along the northern section of the Coromandel Coast, which was relatively less affected by the tsunami than the southern stretches, particularly around the town of Nagapattinam. The lack of extreme human distress, such as was experienced by coastal inhabitants to the south, made it easier for me, as researcher, to focus on the instrumental dimensions of tsunami relief. I argue, however, that collective action of the kind described here took place in all areas where village councils prevail.

\section{The tsunami and the relief effort}

The Coromandel Coast of Tamil Nadu stretches over a distance of 400 kilometres from the border with Andhra Pradesh in the north to Point Calimere, which looks out upon the northern tip of Sri Lanka. This coastline consists of long sloping beaches that are generally uninterrupted by sudden changes of landscape. The 265 fishing settlements that dot the shore, at an average of one hamlet for every 1.75 kilometres of beach, are relatively unprotected. ${ }^{4}$ From the open expanse of the Bay of Bengal come cyclonic storms that beat the shoreline at great velocity, sometimes several times a year. This frequently results in a loss of life, as well as in major physical damage.

The fishing population of this coast, estimated at 273,942 in the year 2000 , belongs mainly to the Pattinavar fishing caste. This marine fishing people has occupied the Coromandel Coast for many centuries. These conditions, as well as the historical isolation of the coastal population from the agrarian hinterland, have contributed to a large measure of social, technical and institutional uniformity, and a significant level of mutual interaction.

\footnotetext{
${ }^{4}$ These figures are calculated from the Department of Fisheries (2000) and do not include the fishing population of the Union territories of Pondicherry and Karaikal.
} 
The Pattinavar have gone along with the times, jumping the bandwagon of fisheries modernisation that commenced in the late 1950s. Many of the fishers made the transition to trawler fishing, and shifted their homes to one of six new harbour locations. The greater part, however, have continued to prefer their rural settlements, grasping instead the opportunities that arose in the modernisation of beach-based fisheries. As will be discussed in section 4 below, self-installed uur panchayats play a paramount role in governing hamlet affairs. As most of the hamlet populations are engaged in fishing, their influence stretches out to this domain.

The tsunami that struck the Coromandel Coast in the early morning of 26 December 2004, washed a coastal zone 300 to 3000 meters wide and caused significant losses to lives and property. The overall damages have been assessed at US\$ 660 million, and the losses at US\$ 410 million (UNDP 2005:3). It wreaked most havoc, in mainland India, in the state of Tamil Nadu. Within Tamil Nadu, the Coromandel coast suffered the greatest damage (Salagrama 2006:164).

The following table provides an overview of the losses incurred in Tamil Nadu, with a specification for the Coromandel Coast. Note that this inventory does not differentiate, as far as loss of life is concerned, between the fishing and the non-fishing population, and also does not include professional assets of categories other than fishers.

\begin{tabular}{|l|r|r|}
\hline Type of loss or damage & Tamil Nadu & \multicolumn{2}{|l|}{ Coromandel Coast } \\
\hline Loss of life & 8,009 & Not specified \\
Lost and damaged fishing boats & 36,080 & 24,526 \\
Lost and damaged fishing nets & 38,177 & 24,515 \\
\hline
\end{tabular}

Table 1: Tsunami losses and damages in Tamil Nadu (Coromandel Coast)

Source: Calculated from Salagrama (2006:165, table 1). These figures do not include the Union Territories of Pondicherry and Karaikal.

The table points out that approximately two thirds of the destruction that took place to fishing craft and gear in Tamil Nadu actually occurred along the Coromandel Coast. Aside from other physical damages - which include beach erosion and loss of public infrastructure such as roads and harbours - Salagrama (2006:168-9) points out the psychological traumas and social distress incurred by survivors of the tsunami. 
The emergency relief effort that picked up in the days and weeks after the disaster was momentous in volume, but also chaotic. One knowledgeable observer, speaking in a public hearing in Chennai, one week after the tsunami took place, therefore referred to the relief wave as a second tsunami. ${ }^{5}$ Goods and volunteers streamed in from all parts of India and the world. The main focus of attention was the fishing population, which had clearly suffered badly. In striving to reach and assist the people who had been affected by the tsunami, government and private agencies met up with the uur panchayats. The next section considers their roles under more regular circumstances.

\section{Uur panchayats' role in more normal times}

Bavinck (2001a,b) has analysed the manner in which so-called uur panchayats (Tamil for hamlet councils) manage the fisheries of the Coromandel Coast of Tamil Nadu. Karunaharan (2006) considers the role these same organisations play in the regulation of fish marketing. The impression that emerges from the various studies is of a full-blown non-state organisation that involves itself extensively in natural resource management as well as in more general village affairs. A similar style of organisation exists along the Hindu coasts of Andhra Pradesh (Salagrama 2005), Pondicherry and Karikal (Bharathi 1999), and the Palk Strait and northern Gulf of Mannar (Bavinck and Karunaharan 2006).

Before considering the functioning of uur panchayats along the Coromandel Coast, it is useful to examine their context. As mentioned above, the marine fisheries of the Coromandel Coast are dominated by the Pattinavar caste. Two points are important to emphasise: the longevity of their occupancy of this coast, and the omnipresence of certain fishing styles and institutional arrangements. Most of the fishing hamlets along the Coromandel Coast are small, single-caste villages, which have been isolated from the main body of Tamil society, and from the strong fingers of government, until relatively recently. Village life is intense and cohesive. This helps to explain why their uur panchayats still possess a large degree of authority.

\footnotetext{
${ }^{5}$ The hearing was organised by a group of concerned citizens on 7 January 2005 at the Madras Institute of Development Studies (MIDS). The speaker in question was V.Vivekanandan. The comparison of the relief effort to a tsunami is also found in the note distributed at the gathering, entitled Towards post-tsunami livelihood security for fishing communities in Tamilnadu - a preliminary proposal from concerned citizens.
} 
What exactly are these uur panchayats and how do they function? Bavinck (2001a,b) points out the existence of various organisational layers. The most obvious is a council of up to ten, generally older men, headed by a person called chettiyar, naaddaar, or president. Elected or appointed for a longer or shorter term, this council takes the lead in community decision-making. It operates, however, in the context of a tradition of village meetings, in which all adult males, or varikaarar (tax payers or village members), participate on the basis of equality. In the villages of the Coromandel Coast, village membership is a formalised affair, for which only those adult males who are involved in fishing can apply. The resultant membership list, which is updated only occasionally, constitutes the basis for the division of collective responsibilities as well as returns.

The uur panchayat is expected to act for the benefit for the village as a whole. This means, on the one hand, that it strives to mollify the village goddess by ensuring the continuity of religious rites. It is called upon to address disputes between village factions, and is expected to keep in mind the interests of weaker sections of the village community, particularly in times of stress. In the period before the instigation of governmental welfare programmes, uur panchayats therefore arranged for the distribution of foodstuffs, particularly during the rainy season when fishing is difficult. Uur panchayats also take action to ensure the survival of widows and other village members affected by personal misfortune.

In addition, uur panchayats have a role to fulfil with regard to the outside world. Police officers and other officials wanting to interrogate the inhabitant of a fishing hamlet in Tamil Nadu generally proceed through the uur panchayat leaders. This practice serves to cushion and protect villagers from the rough-handed manners of enforcement agencies. It also ensures that villages can speak with one voice. Faced with outside threats, or - as we shall see further on, with outside opportunities - fishers tend to rally around their uur panchayats and work as a collective.

The uur panchayat system still enjoys great force and legitimacy in the villages along the Coromandel Coast. One of its main features is decentralisation, which results in each village making its own decisions. As a result of similar circumstances, as well as of mutual interaction, however, council decisions tend to replicate along the coastline. 
This contributes to a large measure of order. The weakness of the uur panchayat system is the limited toolbox for addressing supralocal matters. For issues which require locallevel action, however, the uur panchayats play a paramount role.

\section{Resilience of fisher institutions}

\section{The case of Kalvimanagar}

The tsunami struck the narrow beach of Kalvimanagar, which is located some 30 kilometres south of Chennai, at about 8.30 a.m., after most fishers had landed their craft and families were taking their breakfast. As the central portion of the village is located on a large dune, the wave washed not over but around its edges, destroying several houses, and killing three members of one family, on its way. Most of the approximately eight hundred inhabitants were able to escape by wading through the water and running to the main road, that runs parallel to the coast at about one kilometer distance. That is where regrouping took place. After spending a night in an inland village, the whole population of Kalvimanagar subsequently moved to a vacant plot of land adjacent the main road. A non-governmental organisation provided tents and other facilities, and other supplies quickly began to trickle in. The location next to a busy traffic artery proved to be wellchosen: a raft of relief agencies, as well as private individuals, soon began to appear.

Fishing had meanwhile all but collapsed - a result of the destruction of most fishing gear, as well as the collapse of the market, following the rumour that fish were eating the human corpses that had washed to sea. For an understanding of following events, it is imperative to know a little more about recent village history (cf. Bavinck 2001a: 85, 165-66). Being located close to Chennai, the village of Kalvimanagar, which once used to be surrounded by bushy wastelands called puRampookku, was becoming increasingly fenced in. In fact, over a ten-year period of time, the uur panchayat had made large amounts of money through the sale of puRampookku land to real estate developers, dividing the proceeds amongst village members. All surplus lands, however, had been done away with. Coastal erosion in the 1970s had reduced the beach, now leaving insufficient land for the needs of a growing population. The central dune was fully occupied, and new houses were therefore coming up in the more vulnerable, lower lying areas along the sides. One of the villagers' main preoccupations was therefore: how to obtain more land? 
The villagers had long-since set their sights on a large vacant plot of land alongside the main road - in fact, exactly the piece of land on which they settled in the post-tsunami period. This land belonged to the Union Government of India and was intended for tourism development. The uur panchayat had made various attempts at obtaining rights to this land, through encroachments and petitions to politicians and relevant government agencies. These initiatives, which had cost a substantial amount of money, had not produced the desired effect. The Union Government knew that the land had a high financial value and was extremely reluctant to part with it. This was the situation in 1995, ten years before the tsunami took place. The deadlock persisted for another decade.

One must realise that the politics of Kalvimanagar in this period were far from troublefree (cf. Bavinck 2001a: 165ff). Conflicts about a variety of issues, including the unwillingness of the headman, or chettiyar, to give access to village accounts, were causing great bitterness. The village youth attempted a coup to replace the older members of the uur panchayat with a newly elected guard. Pressure was put on the chettiyar to resign. But all these divisions and in-fights were put on hold after the tsunami. This disaster unified the village and triggered an unprecedented show of collective agency.

It commenced with the organisation of the damage picture. Realising that the volume of relief and rehabilitation is contingent on visual proof, the uur panchayat made three decisions. The first was that no villager would return to the original settlement to live, even though their own residences might be unaffected, but that all would reside in the relief camp. ${ }^{6}$ The second was to leave the debris caused by the tsunami as it was and not to undertake any clearing efforts. ${ }^{7}$ The third measure was the decision not to go fishing. ${ }^{8}$ The intended effect of these three measures was to give the impression of a severely affected fisher population who were badly in shock.

\footnotetext{
${ }^{6}$ The personal costs of this measure were sometimes severe. Thus the widow of one of the prominent village leaders, who died in the relief camp, argued that his death was the result of the cold and damp of the present location. Their house in the village was unaffected by the tsunami.

${ }^{7}$ Well before the tsunami took place, the Grama Panchayat (the lowest tier of state government) had paradoxically made plans to improve one of the village streets and also build a community hall on its outskirts. The starting date for construction had been fixed for early January 2005, and when the researcher entered the settlement in the company of several fishers, a number of labourers were already at work. On seeing the work in progress, one of the fishers swore: 'Why are they doing this now! Why did they clear the area around the building site? Now visitors will not be impressed by the damages!'

${ }^{8}$ The conditions for fishing were in any case not good, as the market had collapsed and many fishers also felt fear of going out to sea. The collective decision, however, roped in individuals who might have taken their chances.
} 
The next step was to maximise collective returns. Uur panchayat members were mobilised to provide 'tours' of the affected village to authorities and potential donors. In the period following the tsunami, several groups of visitors could thus be seen walking through the ruins in the company of panchayat members. The latter inevitably emphasised the severity of the event and the village's dire need. In the case of important guests, such as politicians, higher government officials and large donors, the uur panchayat went to special trouble. It spent lavishly on welcome and thank you ceremonies and invested heavily in bribes. ${ }^{9}$ Due to these efforts or not, the list of visitors to Kalvimanagar during the 12 months following the tsunami is impressive, reading like a who's who of Tamil Nadu and India. ${ }^{10}$

In their efforts to create advantage from the situation, the uur panchayat focused on three categories of goods - relief items, fishing gear and land - for each of which it estimated the village need. The starting point for its calculations were the 267 village members (varikkaarar), defined according to village logic. As noted above, membership in the fishing villages of the Coromandel Coast depends on origin and residence, profession (fishing), and gender (male), and entails participation in a series of collective responsibilities. It is important to note here that the membership list kept by the uur panchayat overlaps with, but still varies substantially from, the lists that are kept by various government departments. These are based on numbers of households (ration cards), registered fishing units and membership in the fisheries cooperative. The discrepancies between the various lists, and the consequences for the distribution of tsunami relief, caused the uur panchayat many headaches.

Consider the distribution of craft and gear. According to the uur panchayat, the village membership list counted 250 active fishermen. ${ }^{11}$ Regardless of whether they actually suffered a loss of craft and gear in the tsunami, these fishers were argued to need 83 fibreglass fishing craft (one craft for each group of three fishers, with a single craft to be shared by four). The uur panchayat's first goal, therefore, was to realise this number of

\footnotetext{
${ }^{9}$ One uur panchayat member estimated the total expenses of representation during 2005 at IRs 600,000 to 700,000. Of this amount, IRs 40,000 had been spent on soft drinks alone.

${ }^{10}$ It includes ministers from the State Government and the Union Government, high-level politicians, senior civil servants, etc.

${ }^{11}$ The remainder of the village membership consisted of widows, non-fishers and migrant workers, none of whom were expected to actively take part in fishing. In order to compensate for their non-receipt of fishing gear, the uur panchayat awarded the members of this category a financial share.
} 
craft, along with suitable outboard engines. Concomitantly it searched for contributions of fishing gear that could be divided amongst the membership. As nets are divided in kilo-units, their distribution is generally easier than in the case of craft.

When it became clear that the first objective of 83 craft and gear would be reached, and that the aid faucet had not yet been closed, the uur panchayat defined yet another goal. Each of the 83 fisher groups would also be given a kattumaram (a traditional log-tied craft), to replace the one they had had before. In order to fulfill the condition of replacement, the panchayat drafted a list of fisher groups and the sizes of the kattumarams which they had previously possessed. Each group would receive a kattumaram according to the earlier size group.

Table 2 presents the results of uur panchayat activity regarding fishing gear as calculated by a key informant from the village.

\begin{tabular}{|l|l|l|}
\hline Items & Nr of units & Nr of donors \\
\hline Fibre-glass boats & 83 & 9 \\
\hline Outboard engines & 83 & 8 \\
\hline Kattumarams & 29 & 2 \\
\hline Nets (4 types) & $83 \times 37 \mathrm{~kg}$ & 6 \\
\hline
\end{tabular}

Table 2: Fishing gear obtained by Kalvimanagar uur panchayat (1/1/05-1/2/06)

On the basis of these figures, the uur panchayat of Kalvimanagar has reason to be proud of itself: one year after the tsunami, it had succeeded in matching village demand and donor supply so that all fisher groups now possessed a new fibreglass boat with engine as well as an adequate amount of new fishing gear. ${ }^{12}$ In addition, there is apparently sufficient money in the pipeline to ensure that each group will also receive a new kattumaram. It must be remembered that all these items are in addition to the craft and gear that survived the tsunami. The question of a possible glut in fishing gear and its consequences for the fisheries will be touched upon below.

12 Bavinck (2001a: 97-98) calculated that an average household in Kalvimanagar in 1995 owned 15.8 kilos of gillnets. Fishing crews were made up of members from one to three households. 
Regarding the land issue, the success of the uur panchayat's strategy cannot yet be determined. The many dignitaries who visited the village in the course of 2005 invariably made promises, and villagers were sure that the matter had been clinched. Later, however, it then became clear that the procedures were far more complicated than expected, and that the last obstacle had not been cleared. During a visit in early February 2006, some villagers, following a positive announcement by the District Collector, believed that the land matter had finally been achieved. Others, however, expressed doubts, and asked the researcher to also put in a good word.

On a related front, however, the uur panchayat's record is impressive. It has managed to keep the village's ranks closed. In spite of the fact that many of the houses in the old location are habitable, and provide much more comfort than makeshift shelters do, all villagers have remained in the refugee camp. The old village now makes a ghostly impression. All fishing activities too have moved to the shoreline adjacent the refugee camp.

\section{The wider picture}

The few studies that have been conducted on the relief process at the grassroots level confirm the picture that has emerged from Kalvimanagar. Salagrama (2006), who conducted an elaborate survey on the post-tsunami situation of fishers on the mainland of India, points out the role of village councils, particularly along the Coromandel coast. He remarks that, 'in many cases, [uur panchayats] acted as a one-stop shop for the rehabilitation agencies (both Government and NGOs) to channel support into the communities'(2006:201).

Gomathy (2006) takes the analysis a step further. In her sensitive analysis of the role of uur panchayats in the post-tsunami relief phase, she notes that these organisations made their own assessments of damages and victims within a few days of the disaster. These assessments played an important role in the subsequent phase, which included the collection and distribution of aid items and money. Her account of the immediate backgrounds for this practice are illustrative. Many respondents in the 35 fishing villages studied thus reported that: 
The initial phase of aid arrival in the village was marked by chaos. When some members of the community received aid, others who did not get it immediately came to know of this and protested. These conflicts had to be resolved at the panchayat level.

To avoid these conflicts, the villagers in many communities collectively agreed to divide the aid received from both the state and the voluntary organisations equitably. Many villages worked out the methods of organising the aid received and redistributing it among the members. In one village, for instance, the panchayatars sat together and decided how to divide the compensation. These calculations were then presented to the larger community and the final amounts negotiated and agreed upon. Those that were unwilling to accede to this decision were to be placed under mariyal [excommunication]. Similar patterns were followed in the distribution of fishing craft compensations from the State (Gomathy 2006:233).

Gomathy places the post-tsunami activities of uur panchayats, as we have done above, in the context of their regular responsibilities. These activities constitute, in other words, an extension of what panchayats, making use of a similar range of goals and instruments, carry out in other circumstances.

The fact that uur panchayats allocated aid according to their own principles sometimes brought them into conflict with the law (Salagrama 2006:202). An interesting example is provided by a newspaper report in The Hindu, 10 June 2005. Five fishing families, who had 'refused to surrender to the panchayat the cash and material relief they received from various service organisations', were excommunicated by the uur pancha$y a t$. The affected families subsequently lodged a complaint with the police against the uur panchayat, and the case was expected to go to the High Court. It is likely, in view of the general opinion about non-state organisations of this kind (see Section 1 above), that the judge will pronounce a severe judgement against the panchayat in question.

Salagrama (2006) and Gomathy (2006) do important service to the understanding of the role of uur panchayats in the post-disaster period. Interestingly, however, their analysis stops with the distribution of relief goods. Although there are suggestions that panchayats entered the relief market in a proactive fashion, soliciting specific items or services, as the panchayat of Kalvimanagar has done, this aspect does not receive explicit attention. These authors also do not place panchayat strategies in a historical perspective something that is possible only if one follows developments over a longer period of time. 
Despite limitations in the supporting evidence, it is unlikely that uur panchayats along other parts of the Coromandel Coast behaved differently from the uur panchayat in Kalvimanagar. It is true that their objectives may have varied to some extent. The interest in obtaining land, for example, is likely to be stronger in the vicinity of towns and cities than in more rural areas. The overall functioning of the uur panchayats, however, and the instruments applied, appear generally to have been the same.

\section{Conclusions}

The 2004 tsunami has triggered a great deal of scholarly reflection, particularly in the field of disaster studies. Members of the Resilience Network, such as Adger et al. (2005), cited in Section 1, have also made reference to incidents of this kind in order to emphasise the value of institutional resilience in preventing larger social disasters. Their attention for non-state structures and processes is worthwhile. It fits into a wider thought process, which has lesser expectations of government and more of market and civil society. Indeed a discussion on the roles of various societal parties has also raged in Tamil Nadu, where in the post-tsunami period it was publicly debated whether government had failed or actually played their expected part, in comparison with other relief and rehabilitation agencies. The notion of resilience describes well the ability demonstrated by uur panchayats along the Coromandel Coast to bounce back and organise the relief and rehabilitation effort on behalf of their constituencies.

But uur panchayats are not only resilient, in the sense that they demonstrate a capacity to react adequately to external incidents. Our evidence suggests that these organisations $a c t$ - they are assertive in their attempts to realise collective goals, which go well beyond the disaster at hand. Such goals are located in the structure and dynamics of local society, and often - as is illustrated in the case of land occupation in Kalvimanagar have historical roots too.

From the point of view of institutional action, disasters such as the tsunami are not fundamentally different from other occasions, which either limit collective options or create opportunities for fishing communities. The discomfort and misfortune precipitated by cyclones and storms need to be countered, as do the guiles of merchants and the mis- 
chievous doings of government. Similarly, fishing communities strive to benefit to the maximum from the providence of a large fish school that appearing the vicinity, or a state-funded welfare scheme. Whether the windfall comes from the sea or from the land, it matters little to the fisher population in question. What counts is that institutions are ready to act, if needed, for a common interest, which includes protecting the weaker sections of the population.

The 2004 tsunami also marks a watershed with regard to the recognition of uur panchayats in Tamil Nadu itself. Some sections of civil society, and government too, consider the strong performance of uur panchayats in the tsunami relief and rehabilitation effort as a pointer for involvement in other matters of public concern, such as natural resource management. Positive attitudes of this kind are contradicted by others, which view uur panchayats as unwanted expressions of a traditional order. The exclusion of women from membership of uur panchayats, for example, has engendered fierce discussion (cf. Thaddeus 2005, Gomathy 2006, Bavinck 2006).

In the meantime it is clear to outside observers that uur panchayats along the Coromandel Coast are under stress. Internal developments - such as the differentiation of village economies, the decline of self-sufficiency and the increasing influence of state politics and policies on village affairs - undermine the foundation upon which uur panchayats are built. Nevertheless these institutions have demonstrated a remarkable ability to adapt to new circumstances. For example, the tradition of hereditary leadership has in recent years generally made way for forms of elected leadership. And whereas leaders in the past were invariably of an older generation, well-educated youngsters are now taking their places. Other changes - such as a more pronounced role for women - may well be on the way.

\section{References}

Adger, WN, Hughes, TP, Folke, C., Carpenter, SR \& Rockström, J. (2005) 'Socialecological resilience to coastal disasters', Science, 309: 1036-39.

Bavinck, M. (2001a) Marine resource management - conflict and regulation in the fisheries of the Coromandel Coast, New Delhi: Sage. (2001b) 'Caste panchayats and the regulation of fisheries along Tamil Nadu's Coromandel Coast’, Economic and Political Weekly, 36 (13): 1088-94. 
(2003) 'The spatially splintered state: myths and realities in the regulation of marine fisheries in Tamil Nadu, India', Development and Change, 34 (4) 63357.

(2005) 'Understanding fisheries conflicts in the South - a legal pluralist perspective', Society and Natural Resources, 18 (9): 805-820.

(2006) 'Don't be hasty and impetuous. Notes on women in fisheries', Samudra 43: $3-5$.

Bavinck, M. \& K. Karunanaran (2006) Legal pluralism in the marine fisheries of Ramnad District, Tamil Nadu, India. IDPAD Working Paper No. 2: 84, available online, <www.idpad.org>

Bharathi, BS (1999) Coromandel fishermen - ethnography of Pattanavar sub-caste, Pondicherry: Pondicherry Institute of Linguistics and Culture.

Fernando, U. \& Hilhorst, T. (2006) 'Everyday practices of humanitarian aid: tsunami response in Sri Lanka', Development in Practice 16 (3\&4): 292-302.

Karunaharan, K. (2006) A study on the role and performance of community panchayat in marine fish production and marketing along the Coromandel Coast, Tamil $N a d u$, Unpubl. PhD thesis, Bharathidasan University, Tiruchirappalli, India.

Lobe, K. \& Berkes, F. (2004) 'The padu system of community-based fisheries management: change and local institutional innlovation in south India', Marine Policy 28 (3): 271-281.

Department of Fisheries (2000) Tamilnadu marine fisherfolk census: year 2000, Chennai: Government of Tamil Nadu.

Gomathy, NB (2006) 'The role of traditional panchayats in coastal fishing communities in Tamil Nadu, with special reference to their role in mediating tsunami relief and rehabilitation. In: Proceedings regional workshop on post-tsunami rehabilitation of fishing communities and fisheries-based livelihoods, 18-19 January 2006, Chennai, India, pp211-244. Chennai: ICSF.

Long, N. (2001) Development sociology: actor perspectives, London and New York: Routledge.

Mandelbaum, DG (1970) Society in India, 2 volumes. Berkeley: University of California Press.

Rao, MG \& Singh, N. (2005) 'India's federal institutions and economic reform', in Kapur, D. and P.B. Mehta, Public Institutions in India, performance and design, pp 351-405, New Delhi: Oxford University Press.

Salagrama, V. (2005) 'Traditional community-based management systems (TCBMS) in two fishing villages in East Godaveri District, Andhra Pradesh, India' in Cunningham, S. and T. Bostock (eds), Successful fisheries management: issues, case studies and perspectives, Delft: Eburon Academic Publishers.

(2006) 'Post-tsunami rehabilitation of fishing communities and fisheries-based livelihoods in Tamil Nadu, Kerala and Andhra Pradesh, India', in International Collective in Support of Fish Workers. Proceedings regional workshop on posttsunami rehabilitation of fishing communities and fisheries-based livelihoods. 18-19 January 2006, Chennai, India, pp 159-210, Chennai: ICSF. 
Thaddeus, S. (2005) 'Tsunami rehabilitation: good intentions alone won't help', Samudra 42: 43-6.

United Nations Development Programme (2005) Tsunami one year after. A joint UN report, India.

$<$ http://www.undp.org.in/dmweb/Tsunami/UN\%20TsunamiFinal.pdf\#search=\% 22joint\%20UN\%20Mission\%20tsunami\%20one\%20year\%20after\%22> (accessed 26-9-2006). 